\title{
EFFECT OF MASS LAYOFFS ON HEALTH INSURANCE EXPENDITURES: THE CASE OF THE OSTRAVA REGION
}

\author{
Jiří Louda, Ondřej Vojáček, Markéta Pechholdová, \\ Miroslav Barták
}

\section{Introduction}

The study of connections between unemployment and its impacts on human health and economy has been the object of research since the US economic crisis in the 1920s (Brenner, 1967; Brenner, 1969; Kasl et al., 1968; Kasl \& Cobb, 1970; Cobb, 1976). Evidence shows that loss of employment negatively affects not only health of individuals who have lost a job but also that of their partners and family members and reduces the life expectancy (Eliason \& Storrie, 2009). Literature contains a detailed description of different factors such as sex, age, socioeconomic status and other, frequently unobserved personal predispositions of individuals, notably initial health, individual frailty, or quality of interpersonal relationships (Bartley, 1994; Šoltés \& Gavurová, 2015; Gavurová \& Vagašová, 2016). In the Czech Republic (CR), it was observed that worsening of population health generally leads to increased consumption of medical services (e.g., Barták \& Gavurová, 2014), induces economic loss through lost production, loss of population welfare and defensive expenditures (purchase of medicines, vitamins, etc., in an effort to reduce the impacts of the stress situation on the health), and has a negative effect on life expectancy.

In contrast to literature abroad (Garcy \& Vågerö, 2012; Kaspersen et al., 2015), the Czech scientific literature does not contain a study that would comprehensively quantify the effect of unemployment on the population health and the effect of the population health affected by unemployment on public budgets. That said, other spheres of effects of unemployment on society are well described (e.g., Kuchař \& Vaska, 2013). Papers published on this topic in domestic literature rely mostly on studies conducted abroad, or deal with funding and monetary compensation for various diseases where unemployment is unambiguously a risk factor (Dlouhý \& Barták, 2013; Gavurová \& Šoltés, 2016). Systematic quantification in the Czech Republic is made impossible by the fact that the employee status is not part of routine vital statistics, thus data on the national, regional and local scale cannot be obtained. Alternatively, unemployment-related cost estimates are made from the point of view of public budgets, but they disregard the effect of unemployment on the population health, or on health insurance expenditures (Čadil et al., 2011). Some authors have dealt with the issue of mass layoffs (Schröder, 2013; Marcus, 2013). In the CR, mass layoffs concern primarily structurally affected regions. In the MoravianSilesian Region, analysed in the present paper, the employer ArcelorMittal Ostrava (abbreviated to AMO) laid off 600 employees in 2011; OKD mining company laid off 250 in September 2013, and another 1,200 jobs in contractor companies disappeared as a consequence. In 2015, OKD laid off over 300 employees, Vítkovice Steel terminated its operations completely, resulting in job losses for about 300 remaining employees. The current developments in the region indicate that more mass layoffs is still very actual topic. For more detailed analysis of regional differences of economic development in last years in the Czech Republic see e.g. Ženka et al. (2017). In this context, we must note the existence of a connection between stricter environmental regulation related to massive investment in greening in connection with Directive 2010/75/EU and its even stricter wording at the national level for big employers in the region and the risk of their departure and/or reduction of operations. The reason for the pressure on the companies is the regulator's effort to reduce the air pollution in the Moravian-Silesian Region and its impacts on the population health 
(see Šrám \& Dostál, 2012) in a situation where the life expectancy for both men and women in the Moravian-Silesian Region is already below the nation-wide average (73.81 years for men and 79.99 for women in the Region in 2013, compared to the national average of 75.91 and 80.80 , respectively).

The objective of the paper is to analyse the health status and health insurance expenditures for employees concerned by the AMO mass layoffs. The paper tests the hypothesis that closing down a large heavy industry facility increases the risk of morbidity among the laid-off population and leads to an increase in healthcare expenditures. Quantification of this hypothesis is based on a data set provided by Česká průmyslová zdravotní pojišt'ovna, a.s. (the primary insurance company of AMO Group employees). The relationship between unemployment and health, including morbidity by cause, is estimated using relative risk indicators.

\section{Unemployment and Health}

Systematic attention is paid to the direction of the causal relation between unemployment and health and its mechanisms. Although the majority of research supports the conclusion that unemployment causes worsening of health (e.g., Gordo, 2006; Kuhn et al., 2009), opposite views also exist. Salm (2009) monitored health of individuals for a period of four years after a job loss and found no statistically significant causal effect of unemployment on population health, although he did find worsened health among the unemployed. Salm (2009, p. 22) states that "many people with health problems voluntarily terminate their employment with respect to their health and prefer to be unemployed". Although the latter perspective is relatively rare in international literature, it indicates the necessity to control the effect of subjective factors on the job loss of specific individuals. One of the approaches to controlling such factors (and the related reverse causality) is to restrict the research only on cases where an entire plant or facility has been closed down. The plant-closure approach eliminates subjective factors on the job loss of specific individuals: all the employees without exception lose their jobs when a plant is closed down (see section 2.1). Results of this type of analysis have been published by Schröder (2013), Kuhn et al. (2009), Schmitz (2011), or Browning and Heinesen (2012).
Even the threat of losing a job is in itself a health risk, in virtually the same extent as unemployment (Kim \& Knesebeck, 2015). In terms of length of unemployment, Gordo (2006) found a significant negative effect of short-term unemployment only on men, and on both sexes for long-term unemployment. Moreover, Kuhn et al. (2009) state that in the short term, only the increase in mental diseases is statistically significant; an increase in somatic diseases can only be proven in longer periods of unemployment.

Particularly in the USA, a job loss is frequently immediately linked to a loss of health insurance and reduced or factually unavailable sophisticated healthcare (e.g., Baicker et al., 2014; Classen \& Dunn, 2012; Lusardi et al., 2015).

An extensive study by Garcy and Vågerö (2012) dealt comprehensively with the effect of unemployment on the population health in Sweden during the recession in 1992-1996, where $23 \%$ of the 3.4 million women and men born between 1931 and 1965 lost a job at some point of the study period. The authors found that long-term unemployment has more serious consequences for men, who respond to it more sensitively. The relationship between the length of unemployment and the risk of mortality is described using a cubic function for men, and a linear function for women. Harris and Morrow (2001) found an up to $37 \%$ increase in mortality (over 10 years after job loss); the most numerous excess deaths resulted from cardiovascular diseases, lung cancer, accidents and suicides. Likewise, Iversen et al. (1987) confirmed that the likelihood of death among the unemployed increased by $40-50 \%$; similar results were achieved by Lundin et al. (2009). Lynge (1997) state that unemployed men show a $40-70 \%$ greater risk of lung cancer, which cannot be justified simply by more frequent smoking but has other causes as well. Wilkins et al. (2008) confirmed higher mortality in population groups with a lower social status, including the unemployed.

The effect of unemployment on young people in Australia aged 15-24 was examined by Morrell et al. (1998), who concluded that young unemployed people, compared to those employed, showed a significant effect of use of marijuana, tobacco and alcoholic products. They also confirmed a strong connection between unemployment and suicides among young 
people. Montgomery et al. (1998) concluded that experience of young people up to 33 years of age with at least three-year unemployment significantly negatively affects their health risk behaviour, notably the use of tobacco products. According to Hammarström and Janlert (2002), even six-month unemployment at a young age (up to 24) has long-term effects on health and health risk behaviour, also manifested at a later age. These include the effect of use of tobacco products (the effect was not confirmed for alcohol), psychic complaints and somatic complaints (in men only).

The literature also frequently discusses the relationship between unemployment and addictions, or risks thereof. Among other risk factors, addictions have a more or less demonstrable effect on the incidence of cardiovascular diseases and neoplasms (Šimrová et al., 2014). Garcy and Vågerö (2012) refer to numerous studies confirming that unemployment is related to increased drinking of alcohol and alcoholism, increased risk of starting to smoke, increased proportion of smokers, and lower probability of quitting smoking. Mullahy and Sindelar (1996) state, that the relationship between alcohol and unemployment has the opposite nature as well. In their survey in the USA, they found that people who use alcohol more than others have greater difficulties finding a job. It can thus be expected that increased use of alcohol in connection with unemployment, as stated above, then negatively affects re-employment of individuals laid off. Likewise, Deb et al. (2011) confirm that increased use of alcohol may be related to unemployment, but they also add that a part of the unemployed may have problems with being overweight. According to Marcus (2012), unemployed non-smokers have a significantly higher probability of starting to smoke than those employed. However, he did not prove that long-term smokers intensify their smoking after a job loss. Marcus (2012) also found an effect of unemployment on body weight. The weight increase is relatively small $(0.3 \mathrm{~kg})$ but clearly demonstrable. Similar results were achieved based on a detailed literature review by Harris and Morrow (2001). Reichert and Tauchmann (2011) found out that a mere threat of losing a job (see above) has a harmful effect on individuals' psychic health. An important social phenomenon that is related to unemployment and negatively affects health as a consequence is the high rate of indebtedness of some unemployed people (Turunen \& Hiilamo, 2014). In a summary, unemployment is related with risky behaviours (drinking, smoking, overweight) and is accompanied by worsening mental health in a short term and by increased incidence of chronic organic disorders in the long run. Poor health is also a reason for quitting the actual job and lowers the chances for re-employment, producing a partially reverse causality. Additionally, an experience with being once unemployed has detrimental health effects even in the later life course.

\subsection{Plant Closure}

Schröder (2013) examined the difference between the effect of unemployment on health in a sample of unemployed people as a consequence of plant closure, and the effect among unemployed whose contract was terminated individually, and then compared the two groups against a sample of population without any experience of unemployment. Among those laid off as a result of plant closure, he found that men suffered depression more often in the long term (but manifestations of physical disease were not as significant), while women showed worse health in general, connected with many chronic conditions. Moreover, women were found more often to become overweight or obese, and were strongly affected by depression. In men laid off individually, only the numbers of chronic diseases were affected; no differences between the groups were found for other health indicators. Browning and Heinesen (2012), who examined the effect of plant closures in Denmark in 1980-2006, concluded that a job loss increases the risk of mortality from cardiovascular diseases, suicides (suicide attempts), traffic accidents, diseases related to alcohol, and mental disorders. Kriegbaum et al. (2008) examined the simultaneous effect of a job loss and a break-up of partnership on the ischemic heart disease. Whereas a breakup of partnership (for men born in Denmark in 1953) on the ischemic heart disease has an effect, a job loss does not. Marcus (2013) examined the effect of plant closure on mental health, concluding that unemployment due to plant closure seems to impair mental health more severely than unemployment in general and that previous studies underestimate the public health costs of unemployment. However, 
there are also studies that do not confirm a clear connection between plant closure and morbidity. For example, Schmitz (2011) analysed the effect of unemployment due to plant closure on mental health of the German population between 1991 and 2008. He states that although the unemployment correlates negatively with health, the same cannot be said in the case of a plant closure, because such a correlation was not clearly confirmed in the group of unemployed people in his study On the one hand, the findings from the plantclosure studies thus indicate that when the laid-off population is not a subject of previous individual selection, the organic health effects may be lower but in general the studies showed that plant closure represents a highly stressful event, resulting in significant worsening of mental health (but according to Schiele \& Schmitz (2016) effect of job loss varies across the mental and physical health distribution. They found out (p. 65) that "effects of job loss on the lower 7 deciles of the distribution of physical health states are negative and considerable in size, while the effects on the upper two deciles are virtually zero").

\subsection{Effect of Economic Crises on Health Systems}

Unemployment is however not the only factor operating on the worsening of the health status. A number of recent studies has dealt with the consequences of an economic recession and crisis and the related impacts on unemployment and health systems. They have analysed both impacts on the health of the (un)employed population and the effect of economic development on funding and monetary compensations within health systems. Evidence is available from both the USA (Lusardi et al., 2015), and Europe, notably Greece (Drydakis, 2015) and Spain (UrbanosGarrido \& Lopez-Valcarcel, 2015), as well as Venezuela in South America (Mansilla, 2016). In Greece, a higher total suicide rate was reported as a consequence of the economic crisis and unemployment, particularly among men (Papaslanis et al., 2016). There are also studies comparing the situation in the EU Member States. These studies point to the fact that in each country the impact of the crisis on health domain was different and the countries used different solutions to deal with these issues (McLeod et al., 2012; Ferrarini et al., 2014). The economic recession, or crisis, has had an effect on health systems in recent years not only in terms of worsened health for some diagnoses in the affected countries, but also limited availability and perceived quality of healthcare (Greece, Spain; catastrophic in Venezuela) and changes in funding in the form of a decrease or at least stagnation of healthcare expenditures measured by a GDP percentage (Cylus et al., 2012; Karanikolos et al., 2013; Kentikelenis et al., 2014). Not even after the economic crisis subsided did the growth in healthcare expenditures match the state before the crisis and, in fact, in several past decades. The rule, almost universally valid in the past, that healthcare expenditures grew faster than the GDP, no longer applies automatically. For example, the healthcare expenditures in Greece decreased by $25 \%$, unprecedented in the OECD, between 2009 and 2013. A decrease in the healthcare expenditures was registered in fact in every third OECD country (OECD 2015).

\section{Methods and Data}

We are comparing the morbidity risk between the employed and unemployed population using individual records of Česká průmyslová zdravotní pojištovna, a. s. (ČPZP). The advantage of the data set provided is that it concerns exclusively the study region and industry and the job loss situation (only AMO employees who terminated their employment in 2008-2013). In the analysed years 2008-2013, there were several waves of layoffs at ArcelorMittal, but some of the employees terminated their employment voluntarily (according to ArcelorMittal (2011), the company offered a severance pay worth 11-24 monthly wages for a voluntary departure).

The data set contains information about 2,265 insured persons, one record per insured person per calendar year $(2,265 \times 6=13,590$ records $)$. The latest records date from the 27 September 2013. The ČPZP data sets contained the following characteristics (variables): insured person ID (primary key); year of birth; sex (male / female); employment status at the time of first diagnosis in the year (identical for all other diagnoses in the year); duration (in months) of employment with AMO in the period 2008-2013; duration (in months) of employment elsewhere in the period 20082013; duration (in months) of employment with 
AMO in total; year of termination of employment with AMO; year of diagnosis (distribution of diagnoses by calendar year); current status (employed / unemployed); costs of treatment of selected diseases (see Tab. 1 for a list of diseases); costs of other treatment; and list of all diagnoses in the calendar year according to the tenth revision of the International Classification of Diseases (ICD-10). The sample included 1,797 men and 468 women, which matches the nature of the AMO industry. A considerable part of the insured persons was in a pension age, so the retirement can be expected as the cause of absence of an employment. For this reason, the analysis was restricted to those born in or after 1955 (the youngest insured person was born in 1994). A population defined in this way better complies with the definition of economically active population. After this modification, the data set contained 1,408 insured persons. Due to the small sample size, the analysis is based on the whole population without a differentiation by sex.

The data enable dual approach to the morbidity study: from the perspective of disease incidence (the incidence of a disease is defined as non-zero expenditures on the disease in the year), or from the perspective of costs (comparing the healthcare costs according to the employment status). This paper deals with both the approaches. We analyse both the all-diseases morbidity as well as selected categories of diseases for which a connection with unemployment has been observed in previous studies. Table 1 lists the categories of selected diseases and their respective codes under ICD-10 that were included in the analysis.

\section{Tab. 1: Overview of analysed diagnoses as per ICD-10}

\begin{tabular}{c|c|c|c|c|c} 
& $\begin{array}{c}\text { Malignant } \\
\text { neoplasms }\end{array}$ & $\begin{array}{c}\text { Circulatory } \\
\text { diseases }\end{array}$ & $\begin{array}{c}\text { Mental } \\
\text { disorders }\end{array}$ & $\begin{array}{c}\text { Alcohol-related } \\
\text { diseases }\end{array}$ & $\begin{array}{c}\text { Other } \\
\text { diseases }\end{array}$ \\
\hline ICD-10 code & C00-C97 & $100-199$ & $\begin{array}{c}\text { F00-F09, } \\
\text { F11-F99 }\end{array}$ & F10, K70, T51 & $\begin{array}{c}\text { Remaining } \\
\text { codes }\end{array}$ \\
\hline
\end{tabular}

Source: ICD-10

The input data contained several limitations. Regarding the status (employed / unemployed), the data do not specify the reason for termination or absence of employment, so we cannot distinguish between the job loss due to the layoff of an individual capable of work and his/her transition to the unemployment due to other forms of job termination (e.g., retirement to old-age, disability pension or parental leave). However, we assume that the majority of departures from AMO at a productive age were caused by layoffs, of which there were several waves in the study period.

We did not obtain any records for a control group, i.e., persons who have not terminated their employment and continue to work with AMO. Besides the reduced size of the sample, this constraint may play a role in the resulting differences: it is possible that the laid-off population was subjected to previous medical selection (the unemployed may include severely disabled people whose illness is the cause of job loss), the job loss may not be manifested significantly for chronically ill individuals over less than six calendar years, etc. Thus, although our analysis works with the term unemployed as the counterpol of the employed, it has to be borne in mind that other reasons of absence of employment are included as well, albeit minority ones.

We did not obtain any data for external causes of diseases classified by causes of injuries. External causes of diseases are normally classified in two ways, namely by the cause of injury (suicide, traffic accident, fall, poisoning; these are codes V01-Y98 in ICD-10), and by type and localisation of the injury (to the head, neck, etc.; codes S00-T98 in ICD-10). ČPZP provided data classified under codes S00-T98, which were thus included in the category "Others", which is why the analysis does not contain the category of accidents and injuries in contrast to most of the international studies presented.

The data provided are essentially a cohort study, where individuals spent a part of the whole period in an employment and a part as unemployed - it is therefore a cohort study 
based on the "person-time" concept where the risk is expressed by intensity rates of incidence (see Holčík et al., 2001). For the analytical purposes, the whole period is regarded as a single time-unit (i.e., possible effect of changes in morbidity in time is ignored), and the loss of employment as the only risk factor studied. With respect to the nature of the data (extent of the sample and almost six years of time), we chose the population study method based on a comparison of the disease incidence rate in the employed status and the unemployed status.

\subsection{The PY Model}

The calculation of the risk rates uses the person-years (PY) concept, commonly applied in demographic and epidemiological analysis (e.g., Sheps, 1966). The personyears calculation is crucial for determining the size of the exposed population, which is the denominator of the intensity rates. Generally, we can say that:

$$
P Y=N \times Y
$$

where $N$ is the total number of individuals studied and $Y$ is the length of the study period; here $N=1,408$ and $Y=5.74$ years. In the case of individual data, the total number of personyears can also be expressed as:

$$
P Y=\sum_{i=1}^{n} Y_{i}
$$

where $n$ is the number of observed persons and $Y_{i}$ is the time spent by the $i^{\text {th }}$ insured person (here, it is the same for everyone, as all the insured persons are studied for the same period of time). The calculation of the statusspecific person-years is based on a breakdown of the study period into the individual duration of employment $\left(Y_{i}^{e m p}\right)$ and duration of unemployment $\left(Y_{i}^{\text {unemp }}\right)$, using the following formula:

$$
P Y=\sum_{i=1}^{n} Y_{i}^{e m p}+\sum_{i=1}^{n} Y_{i}^{u n e m p}
$$

Based on this breakdown, we can plot the status-specific person-years as an age pyramid classified by the year of birth (Fig. 1). The insured persons (selected sample) spent the majority of the total time $(63 \%)$ as employed.

\section{Fig. 1: Person-year structure by year of birth and status}

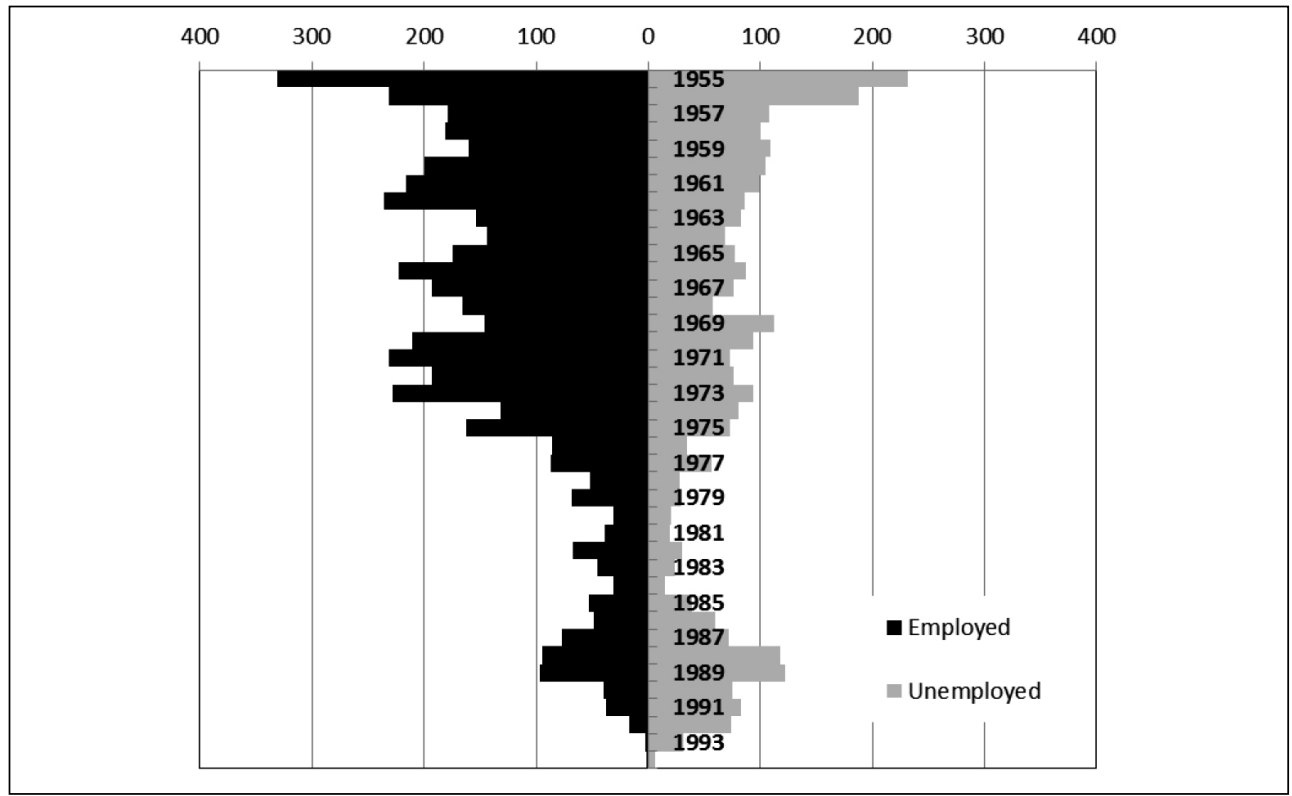

Source: own calculation based on ČPZP data 
Based on the status-specific disease occurrences and person-years, we can calculate the (disease-specific) incidence rates for employed $\left(i r^{\mathrm{emp}}\right)$ and unemployed $\left(i r^{u n e m p}\right)$ persons:

$$
\begin{aligned}
& i r^{e m p}=\frac{d^{e m p}}{P Y^{e m p}} \\
& i r^{\text {unemp }}=\frac{d^{\text {unemp }}}{P Y^{\text {unemp }}}
\end{aligned}
$$

where ir is the incidence rate, $d$ is the number of disease occurrences, and $P Y$ is the number of person-years.

Incidence rates calculated in this way, however, correspond to crude rates and can thus be affected by the difference in age structures of the compared populations. To eliminate the potential effect of difference in age structures, the direct standardisation method was applied, with the relative age structure of the employed individuals as the standard. In order to minimise the effect of random deviations, we are working with five-year cohort groups. To approximate as much as possible the original number of disease occurrences, which are crucial for computing confidence intervals, the total size of the standard population was set as the number of person-years spent unemployed $(\kappa)$ :

$$
\kappa=\Sigma_{x} P Y_{x}^{\text {unemp }}
$$

The standardised numbers of personyears in unemployment by cohort $x$ are then calculated as:

$$
P Y_{x}^{\text {unemp } s t}=\kappa \times \frac{P Y_{x}^{e m p}}{\sum_{x} P Y_{x}^{e m p}}
$$

The standardised numbers of disease occurrences in unemployment in cohort $x$ are obtained by multiplying the standardised population by the observed (crude) cohort incidence rate:

$$
d_{x}^{u n e m p, s t}=i r_{x}^{u n e m p} \times P Y_{x}^{u n e m p, s t}
$$

Thus, the standardised disease occurrences among the unemployed in cohort $x\left(d_{x}^{\text {unemp,st }}\right)$ express how many individuals would become ill in the unemployed population if it had the same age structure as the employed population and the same size as the original unemployed population. In the calculation of the standardised status-specific incidence rate $\left(i r^{s t}\right)$, we then assigned the (aggregated) standardised disease occurrences among the unemployed to the respective (aggregated) person-years:

$$
\text { ir }^{\text {unemp,st }}=\frac{\sum_{x} d_{x}^{\text {unemp }, \text { st }}}{\sum_{x} P Y_{x}^{\text {unemp }, s t}}
$$

The relative difference between statusspecific morbidity is then measured by the socalled incidence rate ratio (irr):

$$
\widehat{\imath r r}=\frac{i r^{u n e m p, s t}}{i r^{e m p}}
$$

To express statistical significance of the point estimates of the irr, we calculate the $95 \%$ confidence intervals. First we calculated the standard deviation (SD) of the $\widehat{\imath r r}$ logarithm as:

$$
S D[\ln (\widehat{\imath r r})]=\sqrt{\left(\frac{1}{\sum_{x} d_{x}^{\text {unemp }, s t}}+\frac{1}{\sum_{x} d_{x}^{\text {emp }}}\right)}
$$

The confidence interval $(95 \% \mathrm{Cl})$ was then calculated as:

$$
\begin{aligned}
& 95 \% C I=\exp \{\ln (\widehat{\imath r r}) \pm 1.96 \times \\
& \times S D[\ln (\widehat{\imath r r})]\}
\end{aligned}
$$

\section{Results}

The resulting ratios of cohort-specific incidence rates are shown in Fig. 2. The relative worsening of health is more apparent for those born in and before 1975 than for the younger ones. At the same time, as these cohorts are more frequent in the sample, the observed estimates have higher statistical significance. However, the medical selection probably also partially plays a role here, as older, thus relatively more ill persons can be expected to have a higher probability of a loss of employment / voluntary retirement from employment (as mentioned by, e.g., Salm, 2009). Although the effect of medical selection cannot be filtered out based on the available data, it has to be borne in mind when interpreting the results that the difference in the morbidity rates might be lower in the case of plant closure. 
Fig. 2: Incidence rate ratio (irr), including $95 \%$ confidence intervals, by cohort

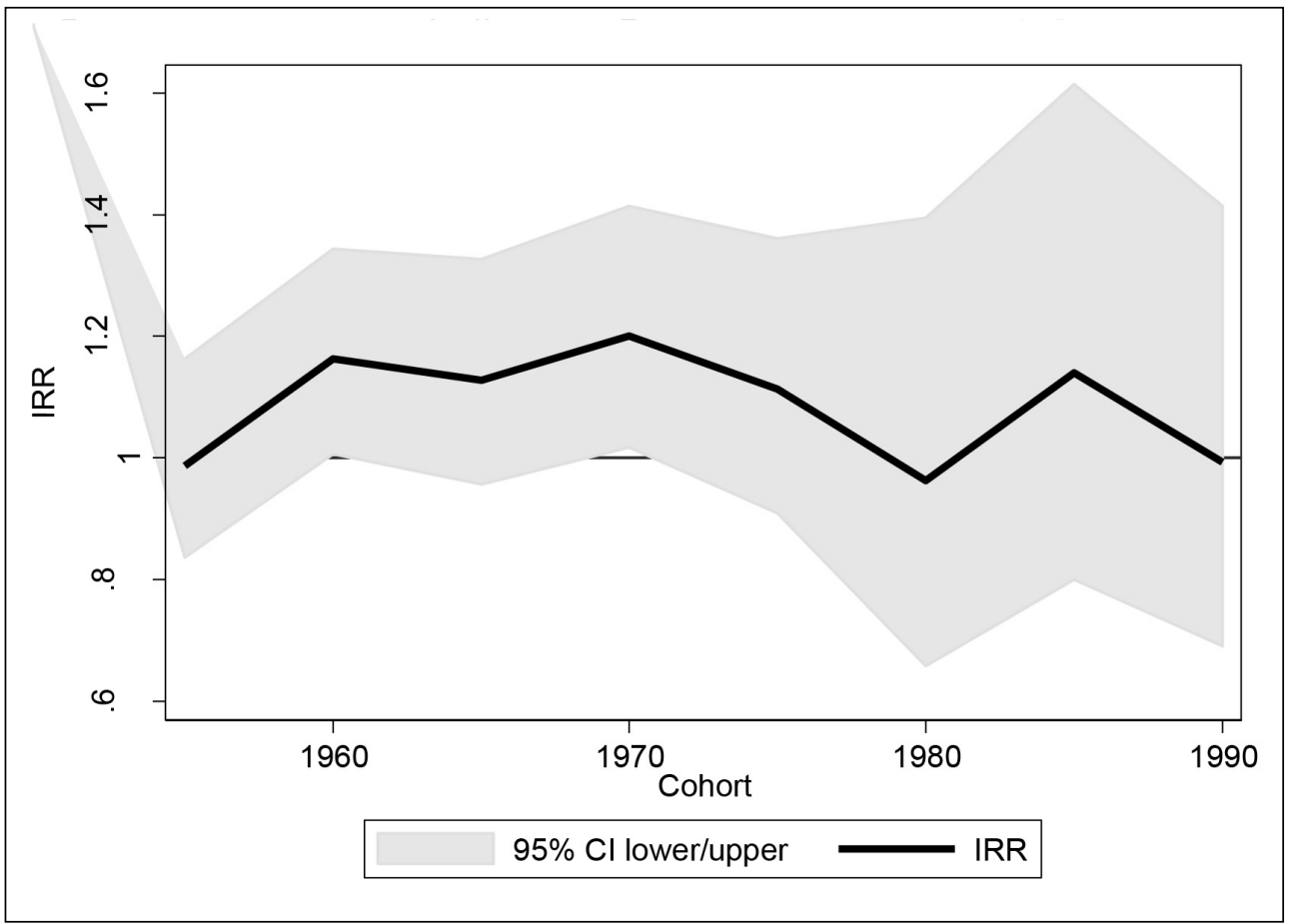

Source: own calculation based on ČPZP data

Tab. 2: Incidence rates (per 1,000 persons) for selected disease categories

\begin{tabular}{l|r|r|r|r|r|r} 
& $\begin{array}{c}\text { Malignant } \\
\text { neoplasms }\end{array}$ & $\begin{array}{c}\text { Circulatory } \\
\text { diseases }\end{array}$ & $\begin{array}{c}\text { Mental } \\
\text { disorders }\end{array}$ & $\begin{array}{c}\text { Alcohol-related } \\
\text { diseases }\end{array}$ & $\begin{array}{c}\text { Other } \\
\text { diseases }\end{array}$ & Total \\
\hline Employed & 9.1 & 116.7 & 33.4 & 9.7 & 244.1 & 412.9 \\
\hline Unemployed & 11.1 & 88.8 & 37.2 & 11.8 & 308.8 & 457.6 \\
\hline Total & 9.8 & 106.3 & 34.8 & 10.5 & 268.2 & 429.6 \\
\hline
\end{tabular}

Source: own calculation based on ČPZP data

The following part of the analysis focuses at selected groups of diagnoses. Tab. 2 contains the age-standardised incidence rates (converted to 1,000 persons of the given status). Among the selected diseases, the summary category "Other diseases" is the most frequent, followed by circulatory diseases. Mental disorders are also a relatively significant component of the morbidity for both the groups.
With the exception of circulatory diseases, we observe a higher morbidity rate among the unemployed persons.

Tab. 3 compares incidence rates of selected diseases and their statistical significance (irr, incl. 95\% confidence intervals). On the whole, the unemployed show $11 \%$ higher morbidity than the employed, and the relationship is statistically significant. 


\section{Ekonomie}

\begin{tabular}{l|c|c} 
Tab. 3: Incidence rate ratios (irr) for selected disease categories \\
\multicolumn{1}{c|}{ Disease } & Incidence rate ratio & $95 \%$ confidence interval \\
\hline Malignant neoplasms & 1.21 & $0.75-1.93$ \\
\hline Circulatory diseases & 0.76 & $0.66-0.88$ \\
\hline Mental disorders & 1.11 & $0.87-1.42$ \\
\hline Alcohol-related diseases & 1.23 & $0.78-1.93$ \\
\hline Other diseases & 1.27 & $1.16-1.38$ \\
\hline Total & 1.11 & $1.03-1.90$ \\
\hline
\end{tabular}

Source: own calculation based on ČPZP data

The irr point estimates of other selected categories of diseases also indicate a higher morbidity among the unemployed, with the exception of circulatory diseases. We observed an increase in the morbidity of the unemployed by $21 \%$ for malignant neoplasms, $11 \%$ for mental disorders, $23 \%$ for diseases related to alcohol, and $27 \%$ for other diseases. However, these relationships are only statistically significant (confidence interval excludes the value 1) for the other diseases category. According to the authors, this result can be attributed to the small population sample and the relatively short study period (less than six years), but it may also be due to the absence of a control group of persons not laid off. We also have to take into account the selection: the persons laid off might have had a worse health already before the layoff, which is why the impact is not so unambiguous.

The following analysis is based on comparison of healthcare expenditures between the employed and the unemployed. We computed average annual costs of treatment per one person-year spent as employed and unemployed. The results are summarised in Tab. 4 below.

The annual costs per insured person at a productive age in the period 2008-2013 were CZK 15,061 without a differentiation by status. We found a significant difference between the annual costs of treatment of employed (CZK 13,420 a year) and unemployed persons (CZK 17,635 a year). The difference of

Tab. 4: Healthcare costs by insured persons' status

\begin{tabular}{c|c|c|c|c|c|c} 
Status & Total & $\begin{array}{c}\text { Malignant } \\
\text { neoplasms }\end{array}$ & $\begin{array}{c}\text { Circulatory } \\
\text { diseases }\end{array}$ & $\begin{array}{c}\text { Mental } \\
\text { disorders }\end{array}$ & $\begin{array}{c}\text { Alcohol- } \\
\text {-related } \\
\text { diseases }\end{array}$ & $\begin{array}{c}\text { Other } \\
\text { diseases }\end{array}$ \\
\hline
\end{tabular}

(a) Average costs per insured person in 1 year

\begin{tabular}{l|r|r|r|r|r|r}
\hline Employed & 13,420 & 541 & 1,288 & 408 & 6 & 11,177 \\
\hline Unemployed & 17,635 & 1,786 & 1,804 & 867 & 23 & 13,155 \\
\hline Total & 15,061 & 1,025 & 1,489 & 587 & 13 & 11,947 \\
\hline
\end{tabular}

(b) Cost index (unemployed / employed)

\begin{tabular}{l|r|r|r|r|r}
1.31 & 3.30 & 1.40 & 2.13 & 3.66 & 1.18 \\
\hline
\end{tabular}

(c) Cost difference (unemployed - employed)

\begin{tabular}{r|r|r|r|r|r|r}
\hline & 4,215 & 1,245 & 516 & 460 & 17 & 1,978 \\
\hline
\end{tabular}


CZK 4,215 means that the costs of treating the unemployed are $31 \%$ higher than those for treating the employed, being higher than the relative increase in the risk of disease $(11 \%$ according to Tab. 3). It follows from the above table that the treatment of the unemployed was costlier than that of the employed.

The increased costliness of treatment for the unemployed was observed in all the disease categories studied. Cancer contributes the most significantly to the higher costliness of treatment for the unemployed (except the residual category of other diseases and preventive interventions). Malignant neoplasms and circulatory diseases are also among the "most expensive" diagnoses. Unlike the circulatory diseases, however, neoplasms (and treatment of their malignant forms) is a convincing reason for terminating work activity, which is why the costs of treating them are significantly lower among the employed. However, this finding points at the effect of selection factors rather than a causal consequence of unemployment.

\section{Discussion}

The review of international literature showed that there is a strong link between unemployment and the health of an unemployed person. The impacts of unemployment range from psychic and psychosomatic disorders to cardiovascular diseases, malignant neoplasms, accidents and suicides. The impact of unemployment on an unemployed person's broader family is also very serious. Long-term unemployment in particular has negative impacts. Long-term effects of several months of unemployment on individuals up to thirty years of age have even been proven (Morrell et al., 1998).

In spite of some methodological constraints due to the type of data obtained, the analysis performed on the data from Česká průmyslová zdravotní pojišt'ovna, a.s., confirmed some of the conclusions of the international studies (see chapter 1). A point increase in morbidity among the unemployed was identified for most of the diseases studied and both the social pathological indicators (alcoholism, mental disorders). However, we observed the opposite relationship for circulatory diseases; the reason may be that the unemployed with cardiovascular complaints seek medical assistance less often, or that leaving the physically demanding work in the steelwork industry temporarily improves the cardiovascular condition and that this type of result only concerns industries with hard manual labour. However, the health impacts of loss of employment are not by any means final. In the context of the data and methodological constraints presented above, these conclusions have to be regarded as the lowerbound estimate of impacts of unemployment on the population studied. Another possible explanation of the increased morbidity for some disease categories, which admittedly contradicts the above statements to some extent, is the fact that the unemployed have more time to see a physician and they would not have the time if they were still employed. Seeing a physician may be of a highly individual nature and may combine additional factors besides the perceived illness, such as sex or age (see Barták, 2010).

In a broader context, the results presented also point at the consequences of the efforts to green big industrial plants in the MoravianSilesian Region with reference to the population health in the Region. The pressure on a high degree of greening and the public debate that accompanies it fail to adequately reflect the risks of potential reduction or closure of production in the Czech Republic and its relocation to countries that do not require such massive investment in so-called cleaner technologies. An extensive body of empirical research documents the impact of the impaired air quality in the Moravian-Silesian Region on the worsened population health (see, e.g., Šrám, 2012; Pohunek, 2012; Švecová et al., 2011; Kodl et al., 2014), but the presented analysis points at the potentially high health impacts in the case of mass layoffs, which can be expected in the heavy industry in the future, (among other reasons also) due to the disproportionate escalation of requirements on greening investment, among other reasons. Considering 1.5-2 "servicing jobs" (see information of the Employment Office in Ostrava, 2013) per employee in a large industrial plant in the Moravian-Silesian Region (Víktovice Holding, OKD, incl. OKD Koksovny, AMO, Vítkovice Steel), then these companies generate a total of 17-44 thousand jobs (depending on the scenario and option; see Louda et al., 2013).

Based on the analysis presented (average increase in cost of treatment of an unemployed person by CZK 4,215), it can be concluded that the annual healthcare costs would increase 
by CZK 74-186 million every year, even if the age structure, disease structure, prices of healthcare and other assumptions discussed above were maintained. These potential indirect costs have to be added to the total direct financial impacts of unemployment in the Moravian-Silesian Region (see Louda et al., 2013). Moreover, the healthcare costs of the unemployed increase in the long run (see, e.g., longitudinal studies; Gordo, 2006; Schröder, 2013) and loss of employment affects the unemployed person's family as well, which feels the negative impact through a lower social status and a stress burden (see Lindo, 2011 or Marcus, 2013). Therefore, we regard the estimate as a minimum.

\section{Conclusions}

The hypothesis that closing down a large heavy industry plant in a structurally affected region will increase the risk of morbidity of the population being laid off, which will secondarily lead to increased healthcare expenditures in the form of ambulatory treatment or hospitalisation, has been confirmed. The analysis showed that the unemployed have $11 \%$ higher morbidity than the employed. The point estimates of all the selected categories of diseases also indicate a higher morbidity among the unemployed in all the disease categories studied, except circulatory diseases. We observed an increase in the morbidity of the unemployed by $21 \%$ for malignant neoplasms, $11 \%$ for mental disorders, $23 \%$ for diseases related to alcohol, and $27 \%$ for other diseases. The relative worsening of health of those born in and before 1975 is more noticeable than for the younger ones. The annual costs per insured person at a productive age in the period 2008-2013 were CZK 15,061 without a differentiation by status. We found a significant difference between the annual costs of treatment of employed (CZK 13,420 a year) and unemployed persons (CZK 17,635 a year). The difference of CZK 4,215 means that the costs of treating the unemployed are $31 \%$ higher than those for treating the employed, being higher than the relative increase in the risk of disease. The discontinuation of 17-44 thousand jobs in the steelwork industry in the Moravian-Silesian Region would thus represent an increase in healthcare costs by at least CZK 74-186 million a year.

\section{References}

ArcelorMittal. (2011). New release: Trvající nejistota na evropských trzích zasáhla poptávku po oceli. Zaměstnancům ArcelorMittal Ostrava bude nabídnut dobrovolný obchod. Retrieved July 11, 2015, from http://ostrava.arcelormittal. com/pdf/183_cz.pdf.

Baicker, K., Finkelstein,A., Song, J., \& Taubman, S. (2014). The impact of Medicaid on labor market activity and program participation: evidence from the Oregon Health Insurance Experiment. The American Economic Review, 104(5), 322-328. https://doi.org/10.1257/aer.104.5.322.

Barták, M. (2010) Ekonomika zdraví: ekonomické, sociální a právní aspekty péče o zdraví. Praha: Wolters Kluwer.

Barták, M., \& Gavurová, B. (2014). Economics and social aspects of long-term care in the context of the Czech Republic and the Slovak Republic EU membership. In Economic Policy in the European Union Member Countries: Conference Proceedings, 12th International Scientific Conference (pp. 16-18).

Bartley, M. (1994). Unemployment and ill health: understanding the relationship. Journal of Epidemiology and Community Health, 48(4), 333-337. https://doi.org/10.1136/jech.48.4.333.

Brenner, M. (1967). Economic change and mental hospitalization - New-York State, 1910-1960. Social Psychiatry, 2(4), 180-188. https://doi.org/10.1007/BF00578054.

Brenner, M. (1969). Patterns of psychiatric hospitalization among different socioeconomic groups in response to economic stress. Journal of Nervous and Mental Disease, 148(1), 31-38. https://dx.doi.org/10.1097/00005053196901000-00004.

Browning, M., \& Heinesen, E. (2012). Effect of job loss due to plant closure on mortality and hospitalization. Journal of Health Economics, 31(4), 599-616. https://doi.org/10.1016/j. jhealeco.2012.03.001.

Classen, T. J., \& Dunn, R. A. (2012). The effect of job loss and unemployment duration on suicide risk in the United States: a new look using mass-layoffs and unemployment duration. Health economics, 21(3), 338-350. https://doi.org/10.1002/hec.1719.

Cobb, S. (1976). Social support as a moderator of life stress. Psychosomatic Medicine, 38(5), 300-314.

Cylus, J., Mladovsky, P., \& McKee, M. (2012). Is There a Statistical Relationship between Economic Crises and Changes in Government 
Health Expenditure Growth? An Analysis of Twenty-Four European Countries. Health services research, 47(6), 2204-2224. https:// doi.org/10.1111/j.1475-6773.2012.01428.x.

Čadil, J., Pavelka, T. et al. (2011). Odhad nákladů nezaměstnanosti $z$ pohledu veřejných rozpočtů. Politická ekonomie, 59(5), 618-637. https://doi.org/10.18267/j.polek.811.

Deb, P., Gallo, W. et al. (2011). The effect of job loss on overweight and drinking. Journal of Health Economics, 30(2), 317-327. https://doi.org/10.1016/j.jhealeco.2010.12.009.

Dlouhý, M., \& Barták, M. (2013). Mental Health Financing in Six Eastern European Countries. E\&M Ekonomie a Management, 16(4), 4-13.

Drydakis, N. (2015). The effect of unemployment on self-reported health and mental health in Greece from 2008 to 2013: a longitudinal study before and during the financial crisis. Social Science \& Medicine, 128, 43-51. https://doi.org/10.1016/j.socscimed.2014.12.025.

Eliason, M., \& Storrie, D. (2009). Job loss is bad for your health-Swedish evidence on causespecific hospitalization following involuntary job loss. Social Science \& Medicine, 68(8), 1396-1406. https://doi.org/10.1016/j.socscimed.2009.01.021.

Ferrarini, T., Nelson, K., \& Sjöberg, O. (2014). Unemployment insurance and deteriorating self-rated health in 23 European countries. Journal of epidemiology and community health, 68(7), 657-662. https://doi. org/10.1136/jech-2013-203721.

Garcy, A., \& Vågerö, D. (2012). The lenght of uneployment predicts mortality, differently in men and women, and by cause of death: A six year mortality follow-up of the Swedish 1992-1996 recession. Social Science \& Medicine, 74(12), 1911-1920. https://doi.org/10.1016/j.socscimed.2012.01.034.

Gavurova, B., \& Soltes, M. (2016). System of day surgery in Slovakia: analysis of pediatric day surgery discrepancies in the regions and their importance in strategy of its development. E\&M Ekonomie a Management, 19(1), 74-92. https://doi.org/10.15240/tul/001/2016-1-006.

Gavurova, B., \& Vagasova, T. (2016). Regional differences of standardised mortality rates for ischemic heart diseases in the Slovak Republic for the period 1996-2013 in the context of income inequality. Health Economics Review, 6(21). https://doi.org/10.1186/s13561-016-0099-1.

Gordo, L. (2006). Effects of Shortand Long-Term Unemployment on Health Satisfaction: Evidence from German Data.
Applied Economics, 38(20), 2335-2350. https://doi.org/10.1080/00036840500427692.

Hammarström, A., \& Janlert, U. (2002). Early unemployment can contribute to adult health problems: results from a longitudinal study of school leavers. Journal of Epidemiology and Community Health, 56(8), 624-630. https://doi.org/10.1136/jech.56.8.624.

Harris, E., \& Morrow, M. (2001). Unemployment is a health hazard: the health costs of unemployment. The Economic and Labour Relations Review, 12(1), 18-31. https://doi.org/10.1177/103530460101200103.

Holčík, J., Koupilová, I., \& Gerylovová, A. (2001). Riziko a jeho míry interpretace: Pojem rizika a relativní riziko. Kardiologická revue, 3(2), 75-78.

Iversen, L., Andersen, O. et al. (1987). Unemployment and mortality in Denmark. British Medical Journal, 295, 879-884. https://doi.org/10.1136/bmj.295.6603.879.

Kaspersen, S. L., Pape, K., Vie, G. Å., Ose, S. O., Krokstad, S., Gunnell, D., \& Bjorngaard, J. H. (2015). Health and unemployment: a 14 years follow-up on labour force exit in the Norwegian HUNT study. The European Journal of Public Health, 26(2), 312-317. https://doi.org/doi.org/10.1093/eurpub/ckv224.

Karanikolos, M., Mladovsky, P., Cylus, J., Thomson, S., Basu, S., Stuckler, D.,... McKee, M. (2013). Financial crisis, austerity, and health in Europe. The Lancet, 381(9874), 1323-1331. https://doi.org/10.1016/S0140-6736(13)60102-6.

Kriegbaum, M., Christensen, U. I., Lund, R., Prescott, E., \& Osler, M. (2008). Job Loss and Broken Partnerships: Do the Number of Stressful Live Event Influence the Risk of Ischemic Heart Disease in Men? Annals of Epidemilogy, 10(18), 743-745. https://doi.org/10.1016/j.annepidem.2008.04.010.

Kentikelenis, A., Karanikolos, M., Reeves, A., McKee, M., \& Stuckler, D. (2014). Greece's health crisis: from austerity to denialism. The Lancet, 383(9918), 748-753. https://doi. org/10.1016/S0140-6736(13)62291-6.

Kim, T. J., \& von dem Knesebeck, O. (2015). Is an insecure job better for health than having no job at all? A systematic review of studies investigating the health-related risks of both job insecurity and unemployment. BMC public health, 15(1). https://doi.org/10.1186/s12889015-2313-1.

Kodl, M. et al. (2014). Zpráva o zdraví obyvatel České republiky. Praha: MZ ČR. 
Kuchař, P., \& Vaska, L. (Eds.). (2013). Regional Aspects of Unemployment in the Czech Republic and Slovakia. Ústí nad Labem: Jan Evangelista Purkyně University.

Kuhn, A., Lalive, R., \& Zweimüller, J. (2009). The Public Health Costs of Job Loss. Journal of Health Economics, 28(6), 1099-1115. https://doi.org/10.1016/j.jhealeco.2009.09.004.

Lindo, J. (2011). Parental Job Loss and Infant Health. Journal of Health Economics, 30(5), 869-879. https://doi.org/10.1016/j. jhealeco.2011.06.008.

Louda, J., Pechholdová, M. et al. (2013). Ekonomické důsledky nezaměstnanosti. In Mediscio society, s. r. o., Envitra CZ, s. r. o., e-Academia, s. r. o. (Eds.), Studie nezaměstnanost a jeji důsledky (pp. 32-47). Ostrava: Statutární město Ostrava.

Lundin, A., Lundberg, L. et al. (2009). Unemployment and mortality - a longitudinal prospective study on selection and causation in 49321 Swedish middle aged men. Journal of Epidemiology and Community Health, 64(1), 22-28. https://doi.org/10.1136/ jech.2008.079269.

Lusardi, A., Schneider, D., \& Tufano, P. (2015). The economic crisis and medical care use: comparative evidence from five high-income countries. Social Science Quarterly, 96(1), 202-213. https://doi.org/10.1111/ssqu.12076.

Lynge, E. (1997). Unemployment and cancer: a literature review. In Kogenvinas, M., Pearce, N. et al. (Eds.), Social Inequalities and Cancer. IARC Scientific Publications, 138, 343-351.

Marcus, J. (2012). Does job loss make you smoke and gain weight? SOEPpapers on Multidisciplinary Panel Data Research, 432, 1-33. https://doi.org/10.2139/ssrn.2020174.

Marcus, J. (2013). The effect of unemployment on the mental health of spouses - Evidence from plant closures in Germany. Journal of Health Economics, 32(3), 546-558. https://doi.org/10.1016/j.jhealeco.2013.02.004.

Mansilla, D. (2016). Venezuela and the International Crisis. In Latin America after the Financial Crisis (pp. 193-227). Palgrave Macmillan US.

McLeod, C. B., Lavis, J. N., MacNab, Y. C., \& Hertzman, C. (2012). Unemployment and mortality: a comparative study of Germany and the United States. American journal of public health, 102(8), 1542-1550. https://doi.org/10.2105/AJPH.2011.300475.
Montgomery, S., Cook, D. et al. (1998). Unemployment, cigarette smoking, alcohol consumption and body weight in young British men. European Journal of Public Health, 8(1), 21-27. https://doi.org/10.1093/eurpub/8.1.21.

Morrell, S., Taylor, R., \& Kerr, C. (1998). Jobless. Unemployment and young people's health. Medical Journal of Australia, 168(5), 236-240.

Mullahy, J., \&Sindelar, J.(1996). Employment, unemployment, and problem drinking. Journal of Health Economics, 15(4), 409-434. https://doi.org/10.1016/S0167-6296(96)00489-4.

OECD. (2015). Focus on health spending. Rertrieved from https://www.oecd.org/health/ health-systems/Focus-Health-Spending-2015. pdf.

Papaslanis, T., Kontaxakis, V., Christodoulou, C., Konstantakopoulos, G., Kontaxaki, M. I., \& Papadimitriou, G. N. (2016). Suicide in Greece 1992-2012: A timeseries analysis. International Journal of Social Psychiatry, 30, 373. https://doi.org/10.1016/ S0924-9338(15)30293-5.

Pohunek, P. (2012). Výskyt astmatu a dalších respiračních onemecnění u školních dětí v Ostravě. Alergie, 3, 169-178.

Reichert, A., \& Tauchmann, H. (2011). The Causal Impact of Fear of Unemployment on Psychological Health. Ruhr Economic Papers, 266, 1-23. https://doi.org/10.2139/ ssrn.1880938.

Salm, M. (2009). Does job loss cause ill health? Health Economics, 18(9), 1075-1089. https://doi.org/10.1002/hec.1537.

Schiele, V., \& Schmitz, H. (2016). Quantile treatment effects of job loss on health. Journal of Health Economics, 49, 59-69. https://doi. org/10.1016/j.jhealeco.2016.06.005.

Schmitz, H. (2011). Why are the unemployed in worse health? The casual effect of unemployment on health. Labour Economics, 18(1), 71-78. https://doi.org/10.1016/j.labeco.2010.08.005.

Schröder, M. (2013). Jobless now, sick later? Investigating the long-term consenquences of involuntary job loss on health. Advances in Life Course Research, 18(1), 5-15. https://doi.org/10.1016/j.alcr.2012.08.001.

Sheps, M. (1966). On the Person Years Concept in Epidemiology and Demography. The Milbank Memorial Fund Quarterly, 44(1), 69-91. https://doi.org/10.2307/3349039.

Šimrová, J., Barták, M., Vojtíšek, R., \& Rogalewicz, V. (2014). The costs and 
reimbursements for lung cancer treatment among selected health care providers in the Czech republic. E\&M Ekonomie a Management, 17(3), 74-85. https://doi.org/10.15240/tul/001/2014-3-007.

Šoltés, M., \& Gavurová, B. (2015). Quantification and comparison of avoidable mortality-causal relations and modification of concepts. Technological and Economic Development of Economy, 21(6), 917-938. https://doi.org/10.3846/20294913.2015.1106421.

Šrám, R. (2012). Vliv znečištěného ovzduší na zdravotní stav populace. Ochrana ovzduší, 5, 4-10.

Šrám, R., \& Dostál, M. (2012). Ovlivňuje znečištěné ovzduší náš zdravotní stav? Medical Tribune, 13. Retrieved July 11, 2015, from http://www.tribune.cz/clanek/26998-ovlivnujeznecistene-ovzdusi-nas-zdravotni-stav.

Švecová, V., Topinka, J. et al. (2011). Faktory ovlivňující personální expozici karcinogenním polycyklickým aromatickým uhlovodíkům v Moravskoslezském kraji a $\mathrm{v}$ Praze $\mathrm{v}$ roce 2009. Ochrana ovzduší, 5-6, 30-35.

Turunen, E., \& Hiilamo, H. (2014). Health effects of indebtedness: a systematic review. BMC public health, 14(1), 489. https://doi.org/10.1186/1471-2458-14-489.

Urbanos-Garrido, R. M., \& Lopez-Valcarcel, B. G. (2015). The influence of the economic crisis on the association between unemployment and health: an empirical analysis for Spain. The European Journal of Health Economics, 16(2), 175-184. https://doi.org/10.1007/s10198-014-0563-y.

Wilkins, R., Tjepkema, R., Mustard, C., \& Choinière, R. (2008). The Canadian census mortality follow-up study, 1991 through 2001. Health Reports, 19(3), 25-44.

Ženka, J., Pavlík, A., \& Slach, O. (2017). Resilience of metropolitan, urban and rural regions: a Central European perspective. GeoScape, 11(1), 25-40. https://doi.org/10.1515/geosc-2017-0003.
Ing. Jiří Louda, Ph.D.

J.E. Purkyně University in Ustí nad Labem

Faculty of Social and Economics Sciences Institute for Economic and Environmental Policy and Charles University Faculty of Humanities

Department of Social and Cultural Ecology Czech Republic louda@ieep.cz

doc. Ing. Ondřej Vojáček, Ph.D. Czech Technical University in Prague

Faculty of Mechanical Engineering Department of Management and Economics and

J.E. Purkyně University in Ustí nad Labem Faculty of Social and Economics Sciences Institute for Economic and Environmental Policy Czech Republic ondrej.vojacek@fs.cvut.cz

RNDr. Markéta Pechholdová, Ph.D. University of Economics Prague Faculty of Informatics and Statistics Department of Demography Czech Republic marketa.pechholdova@vse.cz

PhDr. Miroslav Barták, Ph.D. J.E. Purkyně University in Ustí nad Labem Faculty of Social and Economics Sciences Department of Social Work Czech Republic miroslav.bartak@ujep.cz 


\title{
Abstract
}

\section{EFFECT OF MASS LAYOFFS ON HEALTH INSURANCE EXPENDITURES: THE CASE OF THE OSTRAVA REGION}

\author{
Jiří Louda, Ondřej Vojáček, Markéta Pechholdová, Miroslav Barták
}

The objective of the paper is to make an analysis of the development of health insurance expenditures on healthcare for employees from the mass layoffs from ArcelorMittal Ostrava, a.s. The paper tests the hypothesis that closing down a large heavy industry plant in a structurally affected region will increase the risk of morbidity of the population being laid off, which will secondarily lead to increased healthcare expenditures in the form of ambulatory treatment or hospitalisation. The quantification of this hypothesis is based on a unique non-public data set provided by Česká průmyslová zdravotni pojištovna, a. s., the chief insurance company for employees of ArcelorMittal Ostrava, a.s. The data set contains information about 2,265 insured persons. After some necessary methodological modifications, the analysed data set contained 1,408 insured persons. The relationship between unemployment and health, expressed here as morbidity by cause, is estimated using relative risk indicators. The calculation of the risk rates uses the person-year concept. The analysis carried out showed that the unemployed show $11 \%$ higher morbidity than the employed. We observed an increase in the morbidity of the unemployed by $21 \%$ for tumour diseases, $11 \%$ for mental illnesses, $23 \%$ for diseases related to alcohol, and $27 \%$ for other diseases. The annual costs per insured person at a productive age in the period 2008-2013 were CZK 15,081 without a differentiation by status. We found a significant difference between the annual costs of treatment of employed (CZK 13,420 a year) and unemployed persons (CZK 17,635 a year). The difference of CZK 4,215 means that the costs of treating the unemployed are 31\% higher than those for treating the employed, being higher than the relative increase in the risk of disease. The conclusions confirm findings of published international studies.

Key Words: Unemployment, health, healthcare costs.

JEL Classification: E24, I13.

DOI: 10.15240/tul/001/2018-1-002 